\title{
Histopathological Study of the Kidney after Administration of Methanolic Extract of Roots of Leptadenia hastata in the Albino Wistar Rat
}

\author{
Mama Sy Diallo1* (i), Fatoumata Bah², Chérif Mouhamed Dial3, Cheikh Diop², Oumar Faye1, \\ Matar Seck ${ }^{4}$, Mamadou Fall ${ }^{2}$
}

${ }^{1}$ Laboratory of Histology, Embryology and Cytogenetics, Faculty of Medicine, Pharmacy and Odonto-Stomatology, University Cheikh Anta Diop, Dakar, Senegal

${ }^{2}$ Laboratory of Toxicology and Hydrology, Faculty of Medicine, Pharmacy and Odonto-Stomatology, University Cheikh Anta Diop, Dakar, Senegal

${ }^{3}$ Laboratory of Pathology, Faculty of Medicine, Pharmacy and Odonto-Stomatology, University Cheikh Anta Diop, Dakar, Senegal

${ }^{4}$ Organic and Therapeutic Chemistry Laboratory, Faculty of Medicine, Pharmacy and Odonto-Stomatology, University Cheikh Anta Diop, Dakar, Senegal

Email: ^mamatasy@yahoo.fr

How to cite this paper: Diallo, M.S., Bah, F., Dial, C.M., Diop, C., Faye, O., Seck, M. and Fall, M. (2020) Histopathological Study of the Kidney after Administration of Methanolic Extract of Roots of Leptadenia hastata in the Albino Wistar Rat. Open Journal of Pathology, 10, 67-75. https://doi.org/10.4236/ojpathology.2020.1 $\underline{02007}$

Received: February 10, 2020

Accepted: March 28, 2020

Published: March 31, 2020

Copyright $\odot 2020$ by author(s) and Scientific Research Publishing Inc. This work is licensed under the Creative Commons Attribution International License (CC BY 4.0).

http://creativecommons.org/licenses/by/4.0/

\begin{abstract}
Introduction: The roots of Leptadenia hastata (L. hastata) are remedies from the Senegalese pharmacopoeia and are as widely used as the leaves. However, few researchers have devoted themselves to their toxicity, unlike the leaves. However, in the traditional pharmacopoeia, the indications for use are very different. The aim of our study was to study the effect of the administration of methanolic extracts of roots of $L$. hastata on renal tissue, using an animal model. Materials and Methods: A cohort of 18 rats was studied with a random distribution of the animals in 3 groups $(n=6)$. The first group was the control group. The treated groups (Group II and III) received the methanolic extract of $L$. hastata with an administration of $500 \mathrm{mg} / \mathrm{kg} /$ day and 1000 $\mathrm{mg} / \mathrm{kg} /$ day respectively, for 28 days. Results: The dose of $1000 \mathrm{mg} / \mathrm{kg} /$ day was lethal in group III, from the first week in females. Serum creatinine was significantly higher in rats given the root extract. There was kidney damage with vacuolar degeneration starting at $500 \mathrm{mg} / \mathrm{kg} / \mathrm{day}$. The lesions were more severe in group III with glomerular involvement characterized by retraction in the renal corpuscles. Conclusion: If the leaves of $L$. hastata seem to be safe for consumption according to the majority of authors in the literature, the roots of this same plant could be harmful. In addition to the lethality observed at the doses tested, the lesions in the renal parenchyma would be dose-dependent.
\end{abstract}




\section{Keywords}

Leptadenia hastata, Renal Toxicity, Phytotherapy, Vacuolar Degeneration

\section{Introduction}

The leaves of Leptadenia hastata (L. hastata) are widely used in the Senegalese pharmacopoeia, and in the literature numerous studies have been reported concerning its medicinal properties [1]. Indeed, this plant would have hepatoprotective effects [2] and even a protective effect in case of peptic ulcer [3].

The roots are also used as a remedy, but few toxicity studies have been reported in the literature regarding this part of the plant. The particular use of roots in sickle cell patients in traditional medicine motivated a study carried out in vitro [4]. This revealed a reversible effect on sickle cell red blood cells. Phytochemical screening had made it possible to correlate the flavonoids and the antifalcemic activity of $L$. hastata extracts in this study. Flavonoids are said to have cardiovascular protective properties [5] and are more concentrated in roots than in the leaves of L. hastata [6].

Sickle cell anemia is a genetic disease prevalent in our geographic locality. There is no curative treatment and the disease is responsible for many complications, especially during pregnancy. The treatment is essentially preventive and the therapeutic properties of $L$. hastata in vitro on sickle cell anemia are promising [4]. Only a few studies are dedicated to the roots of $L$. hastata and tissular toxicity is still a subject of research.

The kidney plays a major role in eliminating metabolic waste, especially in the event of toxicity. In addition, renal failure is one of the common complications of hemoglobinopathies but can also be a secondary consequence of the toxicity induced by phytotherapy.

In order to explore in vivo the innocuity of the roots, before eventual clinical assays with patients with sickle cell anemia, we tested the plant using an animal model.

The aim of our study was therefore to study the effects on renal parenchyma, of the administration of methanolic extracts from the roots of $L$. hastata among a cohort of Wistar Albino rats.

\section{Material and Methods}

This study was carried out thanks to a collaboration between the laboratory of Toxicology, the laboratory of Histology-Embryology-Cytogenetics and the laboratory of Pathology of Cheikh Anta Diop University. The experiment was approved by the Ethics Committee of Cheikh Anta Diop University of Dakar (Senegal).

\subsection{Preparation of Plant Extract}

Roots of L. Hastata were collected in the Bush, $18 \mathrm{~km}$ far from Dakar in the lo- 
cality of Sangalcam (Figure 1). The root material was identified and authenticated by expert in the unit of Botanic at the Pharmacy Faculty of Cheikh Anta Diop University of Dakar. Roots were sectioned, washed, and dried without exposition to sun or dust. Five hundred (500) grammes of L. hastata were ground using a laboratory plant grinder. Two hundred (200) grams of the powder obtained was extracted by maceration for 72 hours. A double extraction was carried out with $2 \mathrm{~L}$, then $750 \mathrm{~mL}$ of methanol. After filtration, the extract was evaporated using a rotary evaporator and was placed in an oven at $40^{\circ} \mathrm{C}$ until complete dryness.

\subsection{Rats}

Eighteen Wistar rats with eight to twelve weeks old and average weight of 180 $220 \mathrm{~g}$ were studied. They were raised in plastic cages with wood shavings as bedding. The temperature of the room was maintained at $22^{\circ} \mathrm{C} \pm 4^{\circ} \mathrm{C}$ with 12 hours of light and 12 hours of darkness. The rats had free access to food and water.

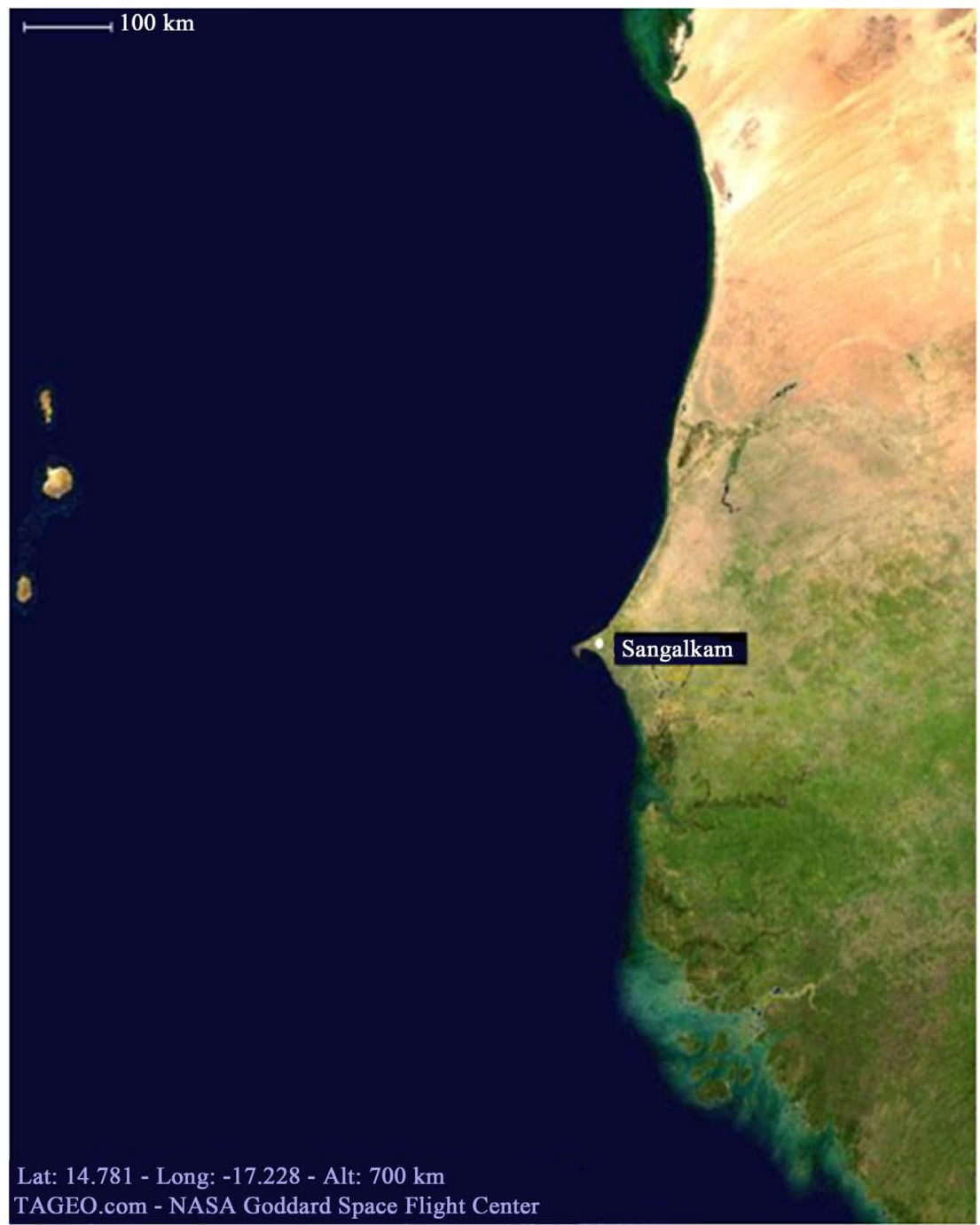

Figure 1. Geographic location of Sangalcam in Senegal. 


\subsection{Administration of the Extract}

The animals were randomly divided into 3 groups $(n=6)$ with equal number of males and females. A stock solution of the $100 \mathrm{mg} / \mathrm{mL}$ concentration extract was prepared with $5 \%$ methanol in mineral water.

Group I the control group, received $2 \mathrm{ml}$ of solution of mineral water containing methanol ( $10 \%$ of total volume).

Group II and III received the methanolic extract of $L$. hastata at doses of 500 $\mathrm{mg} / \mathrm{kg} / \mathrm{j}$ and $1000 \mathrm{mg} / \mathrm{kg} / \mathrm{j}$ respectively for 28 days.

During this period, all the animals were observed daily for signs of toxicity and mortality. The changes in body weight, food and water intake and clinical signs were recorded according to the protocol described in the LD407 of the OECD.

\subsection{Histopathologic Study}

After necropsy, samples from the kidneys were obtained and fixed in buffered formalin (10\%) for at least 24 hours. The samples were dehydrated in graded series of ethanol, cleared in xylene, embedded in paraffin wax and sectioned at 4 $5 \mu \mathrm{m}$. The slides were stained with the Hematoxylin and Eosin (H \& E Stain). Changes were graded as follows: 1) showing no changes, 2) for mild changes (less than 30\%), 3) moderate changes (more than 30\% and less than 50\%) and 4) for severe or marked changes (more than 50\%), following guidelines from the INHAND Project (International Harmonization of Nomenclature and Diagnostic Criteria for Lesions in Rats and Mice) [7].

\subsection{Microscopy}

To analyze the slides, we used photonic microscope from Leica (Leica, microsystems, Wetzlar, Germany), DM 750 and Lasez software to capture and store the images.

\subsection{Biochemical Study}

On day 28, after anesthesia, blood samples were taken from the heart of the animal. Serum was obtained for biochemical analysis after centrifugation at 2500 rpm by min for $15 \mathrm{~min}$. The biochemical indices such as aspartate aminotransferase (AST) and alanine aminotransferase (ALT) transaminases were analyzed. They were assessed in the laboratory of Biochemistry in Diamniadio Hospital using diagnostic kits purchased from Roche Diagnostics Ltd. (Germany).

\subsection{Statistical Analysis}

Results of plasmatic creatinine were expressed as mean \pm standard deviation (SD). The difference between the different groups was compared using test of variance (one-way ANOVA). Differences with values of $\mathrm{p}<0.05$ were considered statistically significant. Statistics were performed using GraphPad software. 


\section{Results}

The methanolic extract from the roots of $L$. hastata was lethal at the tested doses in male and female Wistar rats. At the dose of $1000 \mathrm{mg} / \mathrm{kg} / \mathrm{day}$, deaths were recorded during the first week for females and before the end of the test, all rats in group III were dead.

\section{Creatinine}

Creatinine levels were elevated in Group II. The biostatistical analysis of the biochemical parameters indicated statistically significant between the treated group and the control group. Results are presented in Table 1.

\section{Histology}

\section{Macroscopic examination}

The kidneys were macroscopically normal with brownish color. After section, the parenchyma did not present any sign of particular abnormalities.

\section{Microscopic examination}

Microscopic examination of the kidney revealed vacuolar degeneration in the tubular epithelium in group II and group III and glomerulus lesions. The degree and the topography of these lesions are summarized in Table 2. The lesions were dose-dependent and were more severe in group III (Figure 2). In group III, a retraction of the glomerular floculus was observed within the renal corpuscles (Figure 3).

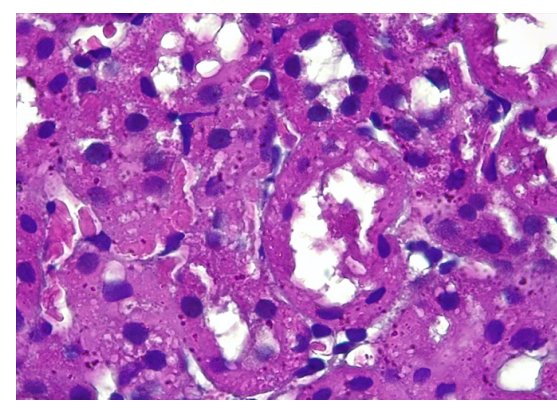

(a)

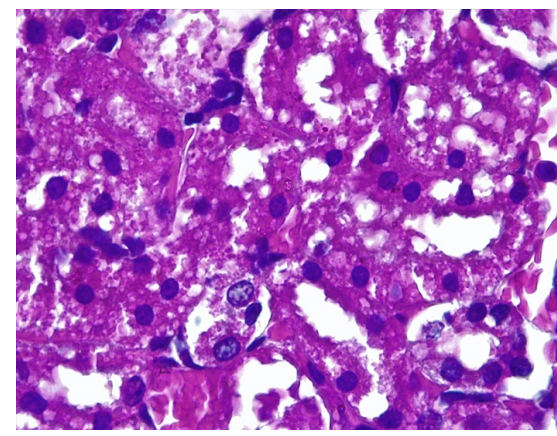

(c)

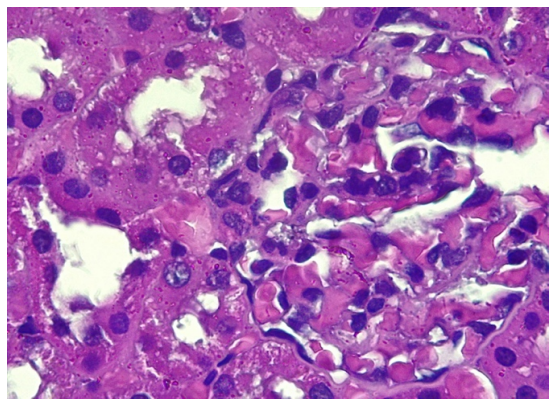

(b)

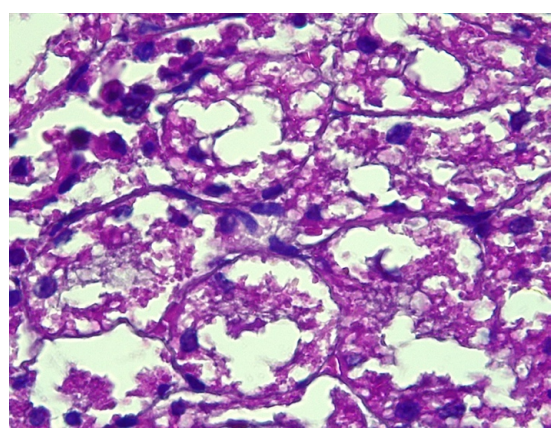

(d)

Figure 2. (a) Normal tubules in control group (HE $\times 400$ ); (b) Normal Renal corpuscle in Group II (HE $\times 400)$; (c) mild vacuolar degeneration of the tubular epithelium in group III (HE $\times 400)$; (d) Severe vacuolar degeneration the tubular epithelium in group III (HE $\times 400)$. 


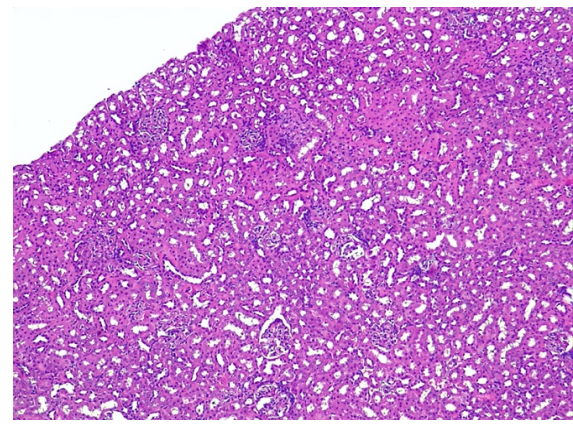

(a)

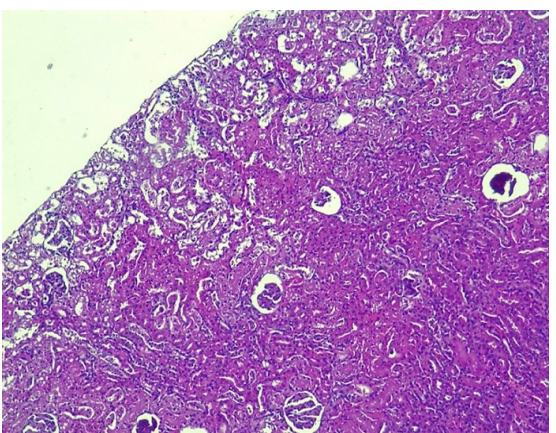

(c)

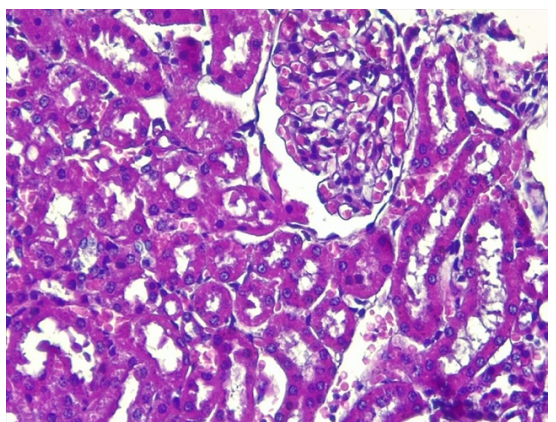

(b)

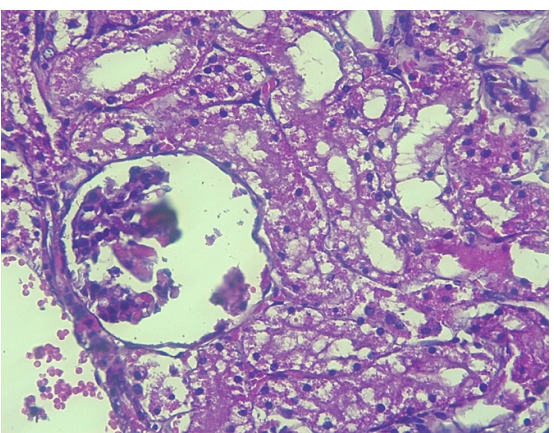

(d)

Figure 3. (a) Normal renal parenchyma in the cortical segment of the kidney with regular tubules and glomeruli $(\mathrm{HE} \times 100)$ and $(\mathrm{b})(\mathrm{HE} \times 200)$; (c) Marked vacuolar degeneration in the subcapsular segment of the renal cortex with retracted glomeruli in enlarged filtration chamber $(\mathrm{HE} \times 100)$ and $(\mathrm{d})(\mathrm{HE} \times 200)$.

Table 1. Renal function in the control group and in group II.

\begin{tabular}{ccc}
\hline & $\begin{array}{c}\text { Group I } \\
\text { Control }\end{array}$ & $\begin{array}{c}\text { Group II } \\
\mathbf{5 0 0} \mathbf{~ m g} / \mathbf{k g} / \mathrm{day}\end{array}$ \\
\hline Creatinine $(\mathrm{mg} / \mathrm{L})$ & Males & \\
& $7.27 \pm 0.46$ & $10.35 \pm 2.47^{* * *}$ \\
Creatinine $(\mathrm{mg} / \mathrm{L})$ & Females & $10.1 \pm 2.32^{* * *}$ \\
\hline
\end{tabular}

$* * *=\mathrm{p}<0.001$ vs. control.

Table 2. Topography and degree of lesions in groups treated with L. hastate.

\begin{tabular}{cccc}
\hline Lesions & $\begin{array}{c}\text { Group II } \\
\mathbf{5 0 0} \mathbf{~ m g / k g / d a y}\end{array}$ & $\begin{array}{c}\text { Group III } \\
\mathbf{1 0 0 0} \mathbf{~} \mathbf{g} / \mathbf{k g} / \mathrm{day}\end{array}$ & Topography \\
\hline $\begin{array}{c}\text { Cytoplasmic vacuolar } \\
\text { degeneration of tubules }\end{array}$ & 1 & 2,3 & $\begin{array}{c}\text { Cortical and } \\
\text { medulla segment } \\
\text { Glomerulus retraction }\end{array}$ \\
\hline
\end{tabular}

\section{Discussion}

\section{Traditional use of $L$ Hastata roots}

The roots of $L$. hastata have specific indications in the traditional pharmacopoeia. These medicinal indications are different from those of other parts of the plant 
such as the leaves or bark [8]. Thus, during ethnobotanical investigations, several authors have reported the medicinal properties of the roots in various conditions such as diarrhea, sexual impotence and gonorrhea but also in the case of abdominal pain [9]. Thus, in breeding, the roots are a usual remedy to treat colic in the horse. It is moreover, following the observation of abortions in mares receiving the roots, that a veterinary study has demonstrated an abortive effect of the plant on a cohort of mice [10].

\section{Therapeutic effect of roots on sickle cell anemia}

Egunyomi [11], and Seck [4], inspired from ethnobotanical investigations to study the roots and its effects on sickle cell anemia [12]. They demonstrated a reversible effect of root extract on sickle-celling red cells in vitro. This reversibility was higher with the methanolic extract, justifying the choice of this extract in our study.

The flavonoids which constitute the most concentrated component of the root [6] promote endothelial function by improving the synthesis of nitric oxide [13] [14] which has a vasodilator effect. This effect on blood volume could have an impact on kidney function, in the groups treated with $L$. hastata root extract.

\section{The tissue damage caused by $L$. hastata roots}

There was cytoplasmic vacuolization in the tubular epithelium with a retracted glomerulus and an enlargement of the filtration chamber. These damages were visible at the dose of $1000 \mathrm{mg} / \mathrm{kg} /$ day. At the dose of $500 \mathrm{mg} / \mathrm{kg} / \mathrm{day}$, vacuolization of the epithelium was present, but the rest of the parenchyma was relatively healthy.

L. hastata is reputed to be a harmless plant, according to most of studies [8]. However, the study by Maurice [15] emphasizes the toxic effects of $L$. hastata when this plant is used with high doses and had reported lethality of Wistar Albinos rats at the dose of $1600 \mathrm{~m} / \mathrm{kg}$ and per day with regard to the aqueous extract of the leaves. In our study, the dose of $1000 \mathrm{mg}$ of methanolic extract from roots was lethal for the rats.

An anti-androgenic effect has also been noted with a decrease in the level of androgens as well as a decrease in spermatogenesis in animal models according to Bayala [16]. Thus, according to the author, because of its properties, the plant (leaves and roots) could be a therapeutic adjuvant in hormone-dependent human cancers such as prostate cancer.

Unlike the leaves, which have been widely studied and documented, few studies are devoted to the roots of $L$. hastata. The results of our study are additional information regarding the safety of this plant. The study also shows that the long-term use of $L$. hastata roots (from $500 \mathrm{~m} / \mathrm{kg} /$ day) causes cellular damage to the kidney.

\section{Conclusions}

The methanolic extract of the roots of $L$. hastata is responsible for damage in the renal parenchyma with vacuolization of the tubular epithelium from a dose of $500 \mathrm{mg} / \mathrm{kg} /$ day. At the dose of $1000 \mathrm{mg} / \mathrm{kg} /$ day, the cytoplasmic vacuolization is 
more severe damage with glomerular damage.

However, the many medicinal properties of the roots of L. hastata and its use in herbal medicine for centuries in West Africa and also in animal husbandry traditions deserve further studies in toxicopathology. The potential promising pharmacological activities on sickle cell anemia are arguments justifying the determination of an effective and safe therapeutic dose for its users.

\section{Conflicts of Interest}

The authors declare that they have no competing interests.

\section{Ethics Approval}

This study received the approval of the ethics Committee from the faculty of Medicine of Cheikh Anta Diop University of Dakar.

\section{References}

[1] Burkill, H.M. (1997) Useful Plants of Western Tropical African. Royal Botanic Garden, Kew, 4,969.

[2] Ojochegbe, A.B., Adejoh, D.P., Boniface, M.T., Duniya, S.V. and Iyaji, A. (2019) Activity of Methanol Extract of Leptadenia hastata Leaves in Alcohol-Induced Liver Injury. American Journal of Biomedical Sciences \& Research, 4, 142-146. https://doi.org/10.34297/AJBSR.2019.04.000785

[3] Umaru, I.J., Badruddin, F.A. and Umaru, K.I. (2018) Effects of Leptadenia Extract on Artemia Salina and Dose Rate on Organs of Ulcer Induced Rats. Asian Journal of Science and Technology, 9, 8436-8439.

[4] Seck, M., Sall, C., Gueye, P.M., Seck, I., Dioum, M.D., Lembachar, Z., Guere, R.S., Fall, D., Fall, M. and Dieye, T.N. (2015) Etude de l'activité antifalcémiante d'extraits de racines de Leptadenia hastata Decne. (Asclepiadacae). International Journal of Biological and Chemical Sciences, 9, 1375-1383. https://doi.org/10.4314/ijbcs.v9i3.22

[5] Tijburg, L.B.M., Malvy, D., Mattern, T., Folts, J.D., Weisgerber, U.M., Katan, M.B. and Brucker, E. (2000) Flavoinoïdes du thé et maladies cardio-vasculaires. Cahiers de nutrition et de Diététique, 35, 135.

[6] Sanda, K.A., Sandabe, U.K., Sanda, F.A., Tijjani, M.B., Majama, Y.B. and Gambo, B.G. (2013) Phytochemical Screening of the Aqueous Root Extract of Leptadenia hastata (Asclepiadaceae) in Maiduguri, Northern Nigeria. Asian Journal of Biochemistry, 8, 33-35. https://doi.org/10.3923/ajb.2013.33.35

[7] Keenan, C.M., Baker, J., Bradley, A., Goodman, D.G., Harada, T., Herbert, R., Kaufmann, W., Kellner, R., Mahler, B., Meseck, E., Nolte, T., Rittinghausen, S., Vahle, J. and Yoshizawa, K. (2015) International Harmonization of Nomenclature and Diagnostic Criteria (INHAND): Progress to Date and Future Plans. Toxicologic Pathology, 43, 730-732. https://doi.org/10.1177/0192623314560031

[8] Bayala, B., Halabalaki, M., Ouedraogo, A., Keiler, M.A., Tamboura, H.H. and Vollmer, G. (2018) Leptadenia hastata Pers. (Decne) a Promising Source for Natural Compounds in Biomedical Applications. American Journal of Drug Discovery and Development, 8, 1-10. https://doi.org/10.3923/ajdd.2018.1.10

[9] Olivier-Bover, B.E. (1986) Medicinal Plants in Tropical West Africa. Cambridge University Press, Cambridge, 375. https://doi.org/10.1017/CBO9780511753114 
[10] Lapo, R.A., Assane, M., Pangui, L.J. and Gbati, O.B. (2003) Study of the Abortifacient Effects of Leptadenia hastata Pers. (Decne). Dakar Medical, 48, 222-225.

[11] Egunyomi, A., Moody, J.O. and Eletu, O.M. (2009) Antisickling Activities of Ethnomedicinal Plant Recipes Used for Ekeke Management of Sickle Cell Anemia in Ibadan, Nigeria. African Journal of Biotechnology, 8, 20-25.

[12] Sofowora, E.A., Isaac-Sodeye, W.A. and Ogunkoya, L.O. (1975) African Medicinal Plants Isolation and Characterization of an Anti-Sickling Agents from Fagara zanthoxyloides Root. Lloydia, 34, 169-174.

[13] Ghosh, D. and Scheepens, A. (2009) Vascular Action of Polyphenols. Molecular Nutrition \& Food Research, 53, 322-331. https://doi.org/10.1002/mnfr.200800182

[14] Ogungbemi, S.I., Anigbogu, C.N., Kehinde, M.O. and Jaja, S.I. (2013) L-arginine Increases Nitricoxide and Attenuates Pressor and Heart Rate Responses to Change in Posture in Sickle Cell Anemia Subjects. Nigerian Journal of Physiologycal Sciences, 28, 45-50.

[15] Maurice, N.A., Garba, A., Maina, V.A., Baraya, Y.S., Owada, A.H., Agang, I., Hambolu, S.E. and Sada, A. (2011) Acute Toxicity Effect of the Leaf Extract of Leptadenia hastata (pers.) in White Albino Rats. Nigerian Journal of Parasitology, 32, 247-250.

[16] Bayala, B., Pellicer-Rubio, M.T., Bassole, I.H.N., Belemtougri, R., Tamboura, H.H. and Malpaux, B. (2011) Effects of Aqueous Extracts of Leptadenia hastate (pers.) decne. (asclepediace ae) on Male Reproductive Functions Using Castrated Immature Rats. Research Journal of Medicinal Plant, 5, 180-188.

https://doi.org/10.3923/rjmp.2011.180.188 